\title{
POZITIVAN UTJECAJ ŽIVOTINJE NA RAZVOJ DJETETA KAO IZAZOV ODGOJITELJSKOJ DJELATNOSTI
}

\author{
Tea Kevac i Tomislav Krznar
}

\author{
Učiteljski fakultet, Sveučilište u Zagrebu \\ Savska 77, 10000 Zagreb \\ e-mail: tomislav.krznar@ufzg.hr
}

\begin{abstract}
Sažetak
U ovom radu nastojimo prikazati neke temeljne odrednice proučavanja pozitivnog utjecaja životinja na razvoj djeteta. Istražujući aspekte dječjeg emotivnog i kognitivnog razvoja, razlažući konkretne uvide o pozitivnom utjecaju životinja na djetetov razvoj, nastojimo doprijeti do pozicije koju možemo promatrati kao temelj suvremene odgojiteljske djelatnosti. S druge strane, sadašnji trenutak postojanja čovjeka obilježavaju brojni problemi širokih razmjera, primjerice, destrukcija prirodnog okoliša ili tehnifikacija života u cjelini. U ovom radu, izmedu ostaloga, postavljamo pitanje o tome kako bismo mogli umanjiti negativni intenzitet spomenutih dogadanja. Smatramo da je rješenja moguće naći u izgradnji bioetičkog senzibiliteta. Temeljni uvidi u nastanak i razvoj bioetike kazuju da je potrebno novo znanje te novi oblik komunikacije / posredovanja tog znanja koji bi bili okrenuti očuvanju života. U suvremenoj odgojiteljskoj profesiji vidimo potencijal za promjene u tom smjeru.
\end{abstract}

Ključne riječi: odgojiteljska profesija, djetinjstvo, razvoj djeteta, životinje, senzibilitet, bioetika

\section{UVOD}

Ovaj rad $^{1}$ nastao je kao rezultat potrage za odgovorima na pitanja o ulozi odgojiteljske djelatnosti u suvremenom društvu. Primarno nas zanima što bi odgojiteljska profesija trebala biti danas. Naime, rijetko koja profesija, ili kako se kazuje „struka“, proteklih decenija prolazi tako velike i korjenite promjene. Odgojiteljska profesija je iznimno složena profesija te njezino obavljanje zahtijeva refleksivno istraživanje odgojno-obrazovne prakse, stvaralaštvo u profesiji te kontinuirani profesionalni razvoj, kreativnost, etičnost i fleksibilnost (Jurčević Lozančić, 2015).

\footnotetext{
1 Ovaj rad nastao je na temelju istraživanja koje je dijelom prezentirano u završnom radu „Etički aspekti rasprave o utjecaju terapeutske životinje na razvoj senzibiliteta djeteta "koji je pripremljen i obranjen u okviru Preddiplomskog studija ranog odgoja i obrazovanja na Učiteljskom fakultetu Sveučilišta u Zagrebu, mentor: doc. dr. sc. Tomislav Krznar, studentica Tea Kevac, datum obrane: 16. rujna 2015. Nastavak istraživanja, također prezentiran u ovom radu, proveden je u okviru potpore istraživanja „Prisutnost bioetičkih sadržaja u nastavi učiteljskih i odgojiteljskih studija“, voditelj doc. dr. sc. Tomislav Krznar, istraživanje financira Sveučilište u Zagrebu.
} 
Svakako možemo ove uvide fundirati u tezi da je obrazovanje, pa tako i odgoj, ključ razvoja nekog društva, oni su oblikovanje budućnosti i ocrtavanje moguće kvalitete života, kako pojedinca tako i društva. Istovremeno, društveni trenutak našeg postojanja obiluje brojnim izazovima i velikim, iznimnim proturječjima. $S$ jedne strane obilje i raskoš, $s$ druge siromaštvo i neizvjesnost. Zasigurno, ovo su samo neki od problema kojima se suvremena odgojiteljska profesija susreće u uzlasku na društvenu i životnu scenu. Društveni mehanizmi, onako kao su oblikovani u zapadnjačkom političkom i ekonomskom konstruktu, sve češće dolaze u pitanje, budući da se u ekonomskom pogledu ukazuju kao nepravedni, u političkom pogledu kao nepostojani, a u odnosu prema cjelini života, neodrživi. Ukoliko pristajemo na tezu da je obrazovanje, (a s „njime“ odgoj) generator budućnosti, ova pitanja trebaju postati i dio interesa onih koji se bave konkretnom praksom odgoja. Naše istraživanje, kojeg dijelom nastojimo predstaviti i ovim radom, ide u smjeru propitivanja novih mogućih inspiracija odgojiteljske djelatnosti posebno iz smjera čovjekova odnosa prema životu. Naime, posljednjih decenija dolazi do sve većih upozorenja o čovjekovom štetnom djelovanju na život (Krznar, 2016), istovremeno dolazi i do upozorenja o promjeni u strukturama postojanja čovjeka samog o čemu svjedoče brojne promjene stanja od malignih bolesti do želje za nadilaženjem hominiteta kakvog poznajemo. O ovim pitanjima već nekoliko decenija postoje rasprave unutar živo pulsirajućeg područja znanja kojeg nazivamo bioetika. Rasprave se vode o pitanjima života i smrti, posebno života čovjeka i njegova odnosa prema životu općenito. Čini nam se opravdanim postaviti i pitanje o ulozi odgojiteljske profesije u ovim procesima, potrazi za tim pitanjima posvećen je ovaj rad.

\section{KAKO JE DJETETU MOGUĆE DOŽIVJETI SVIJET OKO SEBE?}

Pokušajmo naša promišljanja fundirati $\mathrm{u}$, za odgojiteljsku profesiju, obvezujućim pozicijama. Kažimo stoga da razvoj djeteta razumijemo kao slijed promjena u osobinama, sposobnostima i ponašanju djeteta zbog kojih se ono mijenja te postaje sve veće, spretnije, sposobnije, društvenije, prilagodljivije itd. U dječjem razvoju prelamaju se nasljedni (biološki, genetski) i okolinski (učenje, odgoj) utjecaji, ovisi o razvoju neuroloških struktura (mozak, živci). Dječji razvoj dinamičan je proces, zbiva se u socijalnom kontekstu i fleksibilan je. To uključuje tjelesni, spoznajni, emocionalni i socijalni razvoj koji utječu jedan na drugi i razvijaju se usporedno (Starc i sur., 2004). Berk (2008., prema Jurčević Lozančić, 2016) govori o psihologiji cjeloživotnog razvoja te naglašava multidimenzionalni pristup razvoju. Ovdje je razvoj slikovito prikazan poput grana drveta koje se pružaju u različitim smjerovima, a međusobno križanje grana simbolizira da su „područja razvoja tjelesno, kognitivno, emocionalno i socijalno međusobno isprepletena“. Razvoj „pojedinih osobina slijedi svoj osobni ritam, a svaka faza razvoja ima svoje osobitosti“ (Jurčević Lozančić, 2016:88). Možemo kazati da je kod djece nerazdvojno jedinstvo i međuovisnost tjelesnih, psihičkih i socijalnih čimbenika i niti jedan od navedenih se ne može zanemariti. Ili bolje, ,jedno od najvažnijih pedagoških načela je holistički, integrirani i projektni, no istovremeno kreativni, pristup djetetovom razvoju, odgoju i učenju“ "(Jurčević Lozančić, 2016:88). Stoga u ovom dijelu naših promišljanja nastojimo prikazati neke uvide u 
mogućnosti kognitivnog i emocionalnog razvoja djeteta. Brajša Žganec (2003) navodi da emocije utječu na cjelokupno funkcioniranje pojedinca i imaju temeljnu ulogu u interpersonalnom životu, tumače se isticanjem važnosti pojedinih afektivnih, kognitivnih, fizioloških ili bihevioralnih značajki, a sastoje se od niza povezanih reakcija na određeni događaj ili situaciju. One uključuju odnos pojedinca s nekim objektom ili događajem, prepoznatljivo mentalno stanje i emocionalno izražavanje. Uz to, emocije su intenzivne, kratkotrajne te praćene različitim fiziološkim promjenama i uvijek vidljive u trenutnim ponašanjima (Brajša Žganec, 2003). Dijete, prije svega, promatra i oponaša osobe u neposrednoj okolini, a to su njegovi roditelji ili skrbnici. Roditelji imaju najveći direktni i indirektni utjecaj na emocionalni i socijalni razvoj djeteta. $S$ obzirom na današnji ritam života, dijete od najranije dobi polazi odgojne obrazovne ustanove - vrtiće, gdje najmanje šest ili osam sati provodi u okruženju drugih odraslih osoba (i druge djece), koji svojim postupcima i modelom ponašanja također utječu na razvoj djeteta. Zajedno s njihovim roditeljima, odgojitelji sudjeluju u odgoju djeteta.

Ukoliko bismo se htjeli zapitati o kognitivnim dimenzijama razvoja djeteta, u značajnoj knjizi Beba filozof. Što nam djeca govore o istini, ljubavi i smislu života, autorica Alison Gopnik daje vrijedne uvide o spoznajnim, socijalnim i etičkim aspektima razvoja djeteta. Autorica ističe da su sposobnosti djece da mijenjaju svijet veće od onih za koje smo mi mislili da postoje (Gopnik, 2011:15), poglavito u području vrijednosne valorizacije događaja. Poznato je da na razvoj djece posebno utječe pozitivno ozračje njihova odrastanja, djeca mijenjaju roditelje i povratno tom mijenom mijenjaju sebe, no kako Gopnik ističe, djeca imaju sposobnost stvaranja paralelnih, protučinjeničnih svjetova (Gopnik, 2011:25) što im omogućuje unutrašnji rast kroz planiranje budućnosti te drugačiju percepciju kauzaliteta i stvaranje pluralnih mogućnosti vlastitog razvoja. Ponekad ovo rezultira snažnom fikcijom što nam omogućuje da stvaramo svoje psihološke svjetove i time mijenjamo naš fizički svijet (Gopnik, 2011:59). Sve navedeno također rezultira sposobnošću da eksperimentiramo, usavršavamo rezultate svojih eksperimenata i iste ugrađujemo u našu zbilju, to činimo, kako tvrdi Gopnik, putem dva temeljna elementa učenja, konkretno, pažnje i vježbe ponavljanja, čime čak i najmanja djeca izgrađuju svoj identitet oblikovan njihovom sviješću o sebi (Gopnik, 2011:112). U tom pogledu, kako zaključuje spomenuta autorica, (Gopnik, 2011:136) naše djetinjstvo oblikuje našu budućnost kao odraslih ljudi. U ovim procesima moguća je izgradnja empatije dakako i altruizma, a upravo je to temelj moralnosti. Konkretno, onog osjećaja da dijelimo svijet s drugim ljudima, poželjno i s drugim bićima, i da im dugujemo dio svojeg postojanja, onog postojanja koje je oblikovano, kako kaže autorica u ljubavi (Gopnik, 2011:197). Čini se da je ovo važan aspekt koji moramo imati pred očima u promišljanju odnosa čovjeka, posebno djeteta, prema životinjama. Možemo ove uvide povezati na sljedeći način: pozitivno ozračje dovodi do pozitivnog emocionalnog razvoja, a pozitivan emocionalan razvoj dovodi do razvijanja stabilnih crta ličnosti kod djeteta koje su nužne za daljnji kvalitetan razvoj. Kognitivni mehanizmi koje nalazimo i u najmanje djece svjedoče o visokom intenzitetu mogućnosti utjecaja na tijek životnih događanja čak i promjene okružja djeteta. Naše je pitanje sljedeće: može li blizina terapijske životinje, ili životinje općenito, povećati tu mogućnost? 


\section{3. ČOVJEK I ŽIVOTINJA - ZAJEDNIČKA POVIJEST?}

Je li čovjek zapravo životinja, pitanje je koje se provlačilo tijekom cijele povijesti čovječanstva (Morris, 1997). Mnoge teorije donosile su brojne dokaze i protudokaze, no način čovjekova života govorio je za sebe još i više. Svaka osoba, koja je imala priliku boraviti u blizini bilo kakve životinje, govorit će da se životinjski svijet ipak ne sastoji samo od instinkta i borbe za preživljavanjem. Imaju li životinje i razum, samo je jedan od niza pitanja koje si ljudi postavljaju promatrajući životinje. Sve češće iz znanstvenih krugova (Morell, 2013:13) dobivamo informacije da u svijesti životinja postoji nešto mnogo više od onoga što bismo mogli svesti na dimenzije nagona, postoji osjećaj prošlosti i budućnosti, osjećaj za blizinu, bijes, ljutnja i čak nefiziologizirana nježnost. Kako vrijeme prolazi, tehnologija se sve više razvija, ljudi emocionalno postaju otuđeni od životinja (Chernak McElroy, 2002), a mi se ponašamo prema njima kao da su bezosjećajni strojevi ili potrošna roba koja nam stoji na raspolaganju. Ta realnost odražava sve veći i ozbiljniji problem bolesnog stanja, u kojem se čovječanstvo nalazi. Nadalje, možemo zaključiti da naš manjak poštovanja prema životinjama i prirodi odražava duboki, duhovni nesklad naše vrste. No, nove znanstvene spoznaje, kao i osjećaj straha koji je znanstveno-tehnološka moć unijela u naše vrijeme (Krznar, 2016), nalažu nam da pokušamo redefinirati naš odnos prema živom svijetu, posebice prema životinjama. U tom pogledu javljaju se mnoge inicijative na području etologije, biheviorizma, neuroznanosti i sl.

Vrijedi napomenuti da se odnos čovjeka prema životinjama kroz povijest značajno mijenjao, najčešće na štetu životinja. Od početnih, animističkih i divinizirajućih odrednica, do današnjih uglavnom destruktivnih i iskorištavajućih, čovjek je u svom odnosu prema životinjama prošao mnoge faze. Možemo kazati da je znanstveno-tehnička civilizacija izgrađena na tijelima životinja, budući da je koristila njihova tijela kao pogonsku snagu, kao područje istraživanja, kao hranu a ponekad i za zluradu zabavu. Element duhovnosti u odnosu prema životinjama, koji je karakterizirao osvit čovječanstva, ustuknuo je pred koristoljubljem i brutalnosti. Tek suvremeni izvještaji o stradanju životinja, posebno u industrijskom uzgoju, znanstvenim istraživanjima, i sporadičnom uništenju osvještavaju imperativ promjene odnosa čovjeka prema životinjama (Krznar, 2016). Značajan impuls promjena događa se u okrilju bioetike.

Možda je sada prilika da iznova promislimo odnos čovjeka prema živom svijetu, posebno prema životinjama. Čovjek se oduvijek divio životinjama zbog njihove tajnovitosti i moći. To iskazivanje poštovanja prema njima izražavao je na razne načine, od običnog milovanja po glavi, do izgradnje pravih svetišta u njihovu čast. Danas se sve više ističu pozitivni učinci druženja sa životinjama na mentalno i fizičko zdravlje, osobito djece i starijih osoba, te se ono koristi i u terapijske svrhe (Visković, 1996). Susrećemo najčešće izvještaje o terapijskim mogućnostima pasa i mačaka, ali nisu to jedine životinje, koje su se koristile u terapiji. U raznim kulturama koristile su se razne druge životinje primjerice poput lavova, zmija, majmuna itd., i vjerovalo se da je svaka od njih imala svoju individualnu, posebnu moć u tom odnosu.

Posao koji životinje obavljaju, često se događa na suptilnim razinama, navodi Chernak McElroyte objašnjava da je to putem dodira, ali i samim prisustvom životinje (Chernak 
McElroy, 2002). Ponekad je zaista dovoljno da životinje samo sjednu i budu s osobom onoliko dugo, koliko je to dotičnoj osobi potrebno. Brojni su primjeri iz života koji pokazuju kada se susretnu s ljudskim suzama ili tugom, životinje ne okreću glavu kao što to običavaju ljudi, dakle ne bježe od boli. Štoviše, ljudi međusobno ne razgovaraju, okreću glavu jedni od drugih, gledajući samo svoje stvari, gledaju gdje će i od čega imati koristi i kako će iskoristiti nekoga ili nešto. Osobe, koje se rehabilitiraju terapijom životinjama, pokazuju brze napretke. Osoba nauči mnogo o sebi, drugima i svemu ostalom što ga okružuje. Prisutnost životinje može potaknuti na razgovor o vlastitim osjećajima i poimanju života (Chernak McElroy, 2002). Čini se da životinje olakšavaju taj postupak jer pružaju osjećaj sigurnosti i mogućnost za otvaranje osobi koja se za njih brine. Životinje reagiraju pokazivanjem bezuvjetnog pripadanja, ljubavi i prihvaćanja bez procjenjivanja, kritike ili pretjeranih zahtjeva, a osim toga, životinje na svoj osobit način omogućuju ljudima da se osjećaju sigurnim i potrebnima, što se smatra temeljnim ljudskim potrebama (Arambašić i Vizek Vidović, 2000:18).

Kao putokaz u daljnja promišljanja mogu nam poslužiti sljedeće riječi: „pokazalo se da djeca i adolescenti koji su imali traumatska iskustva s drugim ljudima, koja su pokazivala nepovjerenje i strah od drugih ljudi, te manjak samopouzdanja, terapiju uz pomoć životinje doživljavaju kao olakšanje, što smanjuje njihovu psihičku napetost. Kroz terapiju uz pomoć životinja, djeca uspostavljaju kontakt s osobnim emocionalnim životom, jer životinje iz njih izvlače ono duboko humano i za njih važno" (Zuckerman Itković i sur., 2007:163).

\section{MOGUĆNOSTI RAZVOJA DJETETA I UTJECAJ (TERAPIJSKE) ŽIVOTINJE}

Životinje su izravno prisutne u dječjem svijetu, dječji svijet ispunjen realnim ili imaginarnim životinjama koje se pojavljuju u knjigama, crtanim filmovima, filmovima, videoigrama, zoološkim vrtovima, kao i njihovim kućama i dvorištima, stoga nije neobično da se sve veći broj istraživanja bavi analizama odrastanja uz kućne ljubimce i ulogom koju oni imaju u socio-emocionalnom razvoju djece (Smojver-Ažić i Topalović, 2010:172).

Visković tvrdi da od najranijeg doba djecu silno uzbuđuju i privlače prve životinje koje vide (Visković, 1996:237). Te doživljaje prenose na životinjske igračke - platnene, plišane, drvene i plastične psiće, mačke, medvjediće, lavove, žirafe, redom bića koja postaju jedan od prvih i najuspješnijih mostova što spajaju djecu s okolnim svijetom. $S$ njima dijete počinje razlikovati stvari oko sebe - sjedeći na njima, jašući, grizući i stišćući ih. Kazuje dalje Visković da one potiču njegovu moć izmišljanja, predviđanja i stvaranja u mašti objekata i odnosa koje će uspoređivati i primijeniti na ljude u svojoj sredini. Djeca se neizmjerno raduju pričama, basnama, pjesmicama i slikovnicama u kojima opet vladaju likovi iz zoo-a. Ovdje treba zastati i napomenuti da postoji razlika između životinje, kao dijela živog svijeta s kojom čovjek ne može doći u neposredan kontakt, ali je može promatrati iz daljine ili osluškivati njeno postojanje. Nadalje, postoje životinje 
koje (primjerice u ruralnom „proizvodnom“ konstruktu) ljudi koriste u gospodarske svrhe, prema njima najčešće ljudi ne razvijaju osjećaj bliskosti, no mogu (kao što je to slučaj u ruralnim društvima) razviti osjećaj sućuti i milosrđa. Kućni ljubimci su najčešće one životinje koje nemaju posebnu „namjenu“ u ljudskim životima, no igraju značajne uloge u različitim situacijama, od fizičke zaštite do stvaranja emotivne radosti. Naposljetku, tu su i terapijske životinje, posebno uzgojene, odabrane, pripremljene i obučene životinje za pojedine poslove u ljudskom društvu, primjerice briga oko slijepih osoba, tehnička pomoć u raznim situacijama ili životinje pripremljene za konkretne terapijske aktivnosti, poput zaštite osoba oboljelih od epilepsije. U fokusu našeg promišljanja je blizina životinje kao takve, bez posebnih obuka i namjena. Razumije se, ukoliko želimo raspraviti mehanizme pozitivnog utjecaja životinja na zdravlje ljudi ili njihovo fizičko i mentalno stanje moramo uzeti u obzir terapijske životinje, budući da kroz njihovo djelovanje lakše uočavamo pozitivne učinke, no vjerujemo da blizina svake životinje može proizvesti učinak na dobrobit čovjeka.

Primjerice, kako napominju Smojver-Ažić i Topalović, postoje brojna istraživanja koja pokazuju da djeca koja odrastaju uz kućne ljubimce pokazuju više sigurnosti u različitim oblicima djelovanja, no istovremeno i više odgovornosti, privrženosti i empatičnosti u postupcima (Smojver-Ažić i Topalović, 2010:172). Ukoliko polazimo od uvjerenja da je privrženost trajna emotivna veza određenog bića i drugog bića tada nam se izgradnja privrženosti kroz blizinu životinje čini iznimno značajnim fenomenom. Nadalje, iako postoje brojne definicije empatije, svima je zajedničko da se „empatija odnosi na sposobnost razumijevanja emocionalnog stanja druge osobe i proživljavanje iste ili slične emocije koja se očituje i u prosocijalnom ponašanju " (Smojver-Ažić i Topalović, 2010:174). Jasno je da blizina osjećajuće, a često ovisne i bespomoćne životinje, može u djetetu probuditi potrebu za brigom i zaštitom, dijete može iz toga izgraditi osjećaj koji ukazuje na potrebu za stvaranjem onih postupaka koji bi životinji uklonili strah ili povećali razinu radosti. Ovi učinci mogu imati i pozitivno povratno djelovanje na dijete. $U$ spomenutom značajnom istraživanju o ulozi kućnih ljubimaca u socio-emocionalnom razvoju djece Smojver-Ažić i Topalović pokazale su da djeca koja su visoko privržena kućnom ljubimcu imaju i visoko povjerenje prema ljudima (Smojver-Ažić i Topalović, 2010:179), također djeca koja pokazuju visoku privrženost kućnom ljubimcu pokazuju i višu razinu empatije (Smojver-Ažić i Topalović, 2010:182), a u takve djece zapažena je i viša razina prosocijalnog ponašanja (Smojver-Ažić i Topalović, 2010:188).

Već je rečeno, da potencijalno svaka životinja ima mogućnost pozitivnog utjecaja na stanje ljudi, no terapijske životinje pokazuju veće mogućnosti u tom pogledu. Tako Arambašić i Vizek Vidović ističu da postoje dvije vrste terapija u kojima se koriste životinje, terapije uz pomoć životinje i, s druge strane, aktivnosti u kojima sudjeluju životinje (Arambašić i Vizek Vidović, 2000:17). Vrlo je važno razlikovati te dvije vrste djelovanja životinja na ljude kao zasebne djelatnosti, naglašavaju autorice te objašnjavaju da je usmjerena intervencija u terapiji životinjama sastavni dio terapijskog procesa, a terapiju provodi stručnjak. Cilj je takve terapije, povećanje učestalosti poželjnog ponašanja, odnosno ukidanje / smanjenje učestalosti neprikladnih ponašanja. Terapija također služi 
za postizanje vrlo različitih ciljeva poput liječenja fobija, poučavanja novim vještinama, poput hodanja ili komuniciranja, te pomaže pri usvajanju različitih socijalnih vještina. Može pomoći u promicanju tjelesnog i psihičkog zdravlja, ali jedino pod uvjetom da je program unaprijed točno određen i da se dosljedno provodi (Arambašić i Vizek Vidović, 2000:18).

Životinje koje sudjeluju u terapijskom i rehabilitacijskom procesu i životinje koje služe za zabavu nisu isti pojam, već postoje određene razlike, koje objašnjavaju Arambašić i Vizek Vidović. Glavna razlika je u samoj povezanosti čovjeka i životinje, u osobitom odnosu koji se razvija kada osoba ima snažan osjećaj psihološke povezanosti sa životinjom. U takvom odnosu i čovjek i životinja imaju potrebu zadovoljiti potrebe onog drugog. Terapija uz pomoć životinja pretpostavlja utvrđivanje potreba svake osobe i shodno tome postavlja ciljeve terapije, odabir životinje koja najbolje odgovara osobi, unaprijed određenu vrstu i količinu interakcija između čovjeka i životinje te postupke procjene uspješnosti tretmana. Prije početka terapije važno je utvrditi je li osoba imala kućnog ljubimca i kojeg te pokazuje li još uvijek interes za životinje. Spomenute autorice ističu sljedeće psihološke potrebe koje mogu biti zadovoljene terapijom uz pomoć životinja, to su: briga za druge, odnos prema rođenju i smrti, potrebe za samopoštovanjem, odgovornost i upravljanje vlastitim postupcima, osjećaj povjerenja i potreba za slobodnim izražavanjem misli i osjećaja (Arambašić i Vizek Vidović 2000:20). Do sada su isprobani mnogi postupci terapijskog rada sa životinjama, no svakako dvije vrste se koriste najčešće, a to su psi i konji. Pri tome, čini se vrijednim istaknuti nekoliko sljedećih pozicija. Uključivanje terapijskog psa $\mathrm{u}$ rad $\mathrm{s}$ djecom događa se $\mathrm{s}$ ciljem ubrzavanja napretka razvojnog procesa djeteta i pas je medij koji omogućava da se razvije ono što bi možda ostalo skriveno, potisnuto ili nedostupno (Kobešćak i sur., 2013:209). Važno je napomenuti da se sve aktivnosti odvijaju na tri različita područja: socio-emocionalnom, motoričkom i komunikacijskom (Kobešćak i sur., 2013:211). U spomenutom istraživanju autorice su ustanovile su da je blizina terapijskog psa otvorila mogućnosti rada roditelja s djecom koje do tada nisu bile zapažene, kao i to da aktivnosti koje djeca provode s psom pozitivno utječu na njihov tjelesni razvoj budući da obavljaju cijeli niz aktivnosti sa psom koje omogućuju permanentnu vježbu i usavršavanje pokreta, no istovremeno učvršćuju i svijest o vlastitim mogućnostima i sposobnostima. Ponajviše, blizina terapijske životinje olakšava komunikaciju s drugim ljudima, jer daje djetetu sigurnost i ekspertnost u pojedinoj temi, onoj vlastitoj terapijskoj životinji (Kobešćak i sur., 2013:213).Vrijedi također istaknuti da terapijske životinje imaju značajnu ulogu u radu s djecom kao i u aspektu nadilaženja ograničenja urbanih sredina (Zuckerman Itković i sur., 2007:158) budući da takav način života daje djetetu ograničenu sliku u cjelini zbilje te omogućuje lakše dohvaćanje biološke komponente vlastitog postojanja. Nadalje, kako ističu spomenute autorice, pozitivan utjecaj životinje vidimo i u reduciranju sklopa problema koji autorice nazivaju kompjuterizacija odgoja (Zuckerman Itković i sur., 2007:159) što je zbirni naziv za način života koji je previše usmjeren na elektroničke artefakte i medijske podražaje pa može izazvati niz poremećaja u ponašanju djeteta, od senzo-motoričkih, preko poremećaja pažnje i koncentracije, do pogrešnog 
razumijevanja vlastitog identiteta. Blizina životinje čini kod djeteta stalnu potrebu za istraživanjem i djelovanjem, a aktivnost koju zahtjeva životinja stoji nasuprot jednoličnosti i pasivitetu elektronički posredovanih sadržaja.

Uz to, potrebno je nadalje istaknuti posebno područje interakcije ljudi i terapijskih životinja, a to je terapijsko jahanje. Autorice Itković i Boras navode da se zdravstveno-pedagoško jahanje „prije svega odlikuje odgojnom funkcijom. Sam pojam podrazumijeva pedagoške, psihološke, fizioterapijske, rehabilitacijske i socio-integrativne ponude tretmana putem terapijskog jahanja. Riječ je o individualnom napretku osobe preko medija konja, koji ima povoljni utjecaj na njezin razvoj, zdravstveno stanje i ponašanje“" (Itković i Boras, 2003:74). S druge strane, voltižiranje razumijevamo kao vid „pedagoškog jahanja koji u središtu ima jahanje radi ophođenja s konjem. Ono je u potpunosti usmjereno na razvoj i poboljšanje emocionalnog, duševnog, tjelesnog i socijalnog stanja osobe" (Itković i Boras, 2003:74). Ciljevi spomenutih djelatnosti, kako napominju autorice, mogu se raščlaniti na sljedeća područja: područje motorike, emocionalno-spoznajno područje i socijalno područje koja se, svako za sebe, grana u niz različitih aspekata (Itković i Boras, 2003:75). Svakako je ovdje važno napomenuti da je, osobito terapijsko jahanje, vrlo učinkovit alat za suočavanje s brojnim zdravstvenim, kako tjelesnim tako i psihičkim, smetnjama i problemima, kao što rječito navode spomenute autorice: „Sa svojim osobinama, u programu terapijskog jahanja, konj može poslužiti kao instruktor u stjecanju sposobnosti i vještine prepoznavanja emocija, njihove kontrole i pravilnog usmjeravanja. Konj doista može pomoći čovjeku da postigne sklad sa samim sobom i sa svijetom oko sebe. To je potrebno svakom čovjeku bez iznimke, pa se program terapijskog jahanja, pored nabrojanih indikacija i kontraindikacija, može koristiti i preventivno, naročito kod mladih. Svaki mladi čovjek, i bez evidentnog hendikepa ili problema, treba pomoć da stekne samopouzdanje, povjerenje u sebe i druge, osjećaj vlastitog smisla i svrhe življenja. Komunikacija s konjem daje snagu, sposobnost i sigurnost“ (Itković i Boras, 2003:79). Vidimo iz ovih pozicija široki spektar mogućnosti vezan uz problematiku odnosa djeteta prema živom svijetu, sada nam je potrebno razmotriti sljedeće pozicije.

\section{BIOETIČKI IZAZOVI ODGOJITELJSKOJ PROFESIJI}

Kao što je rečeno u prethodnom tekstu ovog rada, kontekst života suvremenog čovjeka iznimno je složen, obilježen brojnim proturječjima i otvoren velikim pitanjima. Nikada u svojoj povijesti čovjek nije živio u takvom obilju, raspolagao $s$ takvim mogućnostima, niti bio u prilici tako intenzivno i nepovratno mijenjati sebe i svoj svijet, uključujući temeljne obrasce života. Sve značajniji upiti oko početka i kraja života, mogućnosti presađivanja organa ili čak (genetičkih ili informatičkih) preinaka čovjeka, uništenja brojnih oblika života i nesmiljene eksploatacije prirodnih resursa, od razine tvari do razine zapisa života, emisija štetnih tvari u okolišu, brutalni uzgoj životinja za hranu ljudima i drugim životinjama, genetičko modificiranje organizama i ekonomska eksploatacija takvih organizama, uništenje kulturne različitosti i neoimperijalni zahvati u političkim 
djelovanjima, pojava sve većeg i opasnijeg siromaštva. Stoga ne iznenađuje da bioterorizam i brojna druga pitanja već dugo zaokupljaju brojne znanstvenike i aktiviste. Suvremenom čovjeku nedvojbeno treba novi oblik znanja, novi oblik pogleda na život i novi oblik komunikacije, konkretno posredovanja znanja u vrlo izazovnim društvenim okolnostima. Interdisciplinarno područje bioetike, osobito u izrijeku integrativne bioetike koja svojim tematskim i metodološkim određenjima želi izići i nedostatnosti koje nalaže interdisciplinarnost, nastoji dati odgovore na spomenuta pitanja, no još i više želi dati konkretne putokaze za konkretno djelovanje u konkretnim ljudskim situacijama. Ukoliko prihvaćamo supstancijalno određenje bioetike (Krznar, 2016:190) kao onog područja znanja koje se bavi životom u cjelini, i ako prihvaćamo da je bioetika ono multidimenzionalno, kako metodološki tako i tipologijski, područje znanja koje ne želi samo objasniti probleme nego i dati konkretna rješenja, čini nam se nezaobilaznim zaključiti da je bioetici potreban mehanizam prenošenja stečenih spoznaja u najšire modele društvenog događanja. Ostaje otvoreno pitanje kakvi bi to trebali biti obrasci znanja i kako / kada bi oni trebali biti izgrađeni da bismo mogli računati s promjenama u odnosu na stanja izrečena ranije.

Možda nije ni potrebno posebno dodati, no rečeni problemi ne mogu biti otklonjeni $\mathrm{u}$ istom horizontu svijesti u kojemu su nastali. Rješenja se ne mogu posredovati istim načinom komunikacije kakvom / kakvima su nastali. Ukoliko bismo tražili zajedničko obilježje ranije navedenim problemima možemo ga naći u osjećaju superiornosti kojom čovjek sam sebe odlikuje, u sklopovima osjećaja, uvjerenja, znanja i komunikacije koji rezultiraju dominacijom nad cjelinom života. Potreban je novi sklop znanja i vrijednosti, novi mehanizam komunikacije i novi temelj za djelovanje. Sve rečeno možemo nazvati bioetičkim senzibilitetom. Bioetičkim jer je izgrađen u okrilju nove paradigme znanja, konkretno, bioetičke paradigme znanja (Krznar, 2016:199), a senzibilitetom jer nastoji očuvati život u svim njegovim oblicima i pojavnostima, a ne djelovati kao da je riječ o gradivnom elementu ljudske komocije. Čini se opravdanim zapitati gdje bi bilo potrebno graditi to novo razumijevanje čovjekova postojanja? Odgovor je, vjerujemo, jasan, u okviru odgojiteljske djelatnosti.

Suvremene teorije (Jurčević Lozančić, 2016) uočavaju brojne probleme suvremenog čovjeka i teže izgradnji kvalitetnih alata kojima bi se u djece rane predškolske dobi mogli razviti oni učinci koji bi omogućili kvalitetno odrastanje u zrelu ljudsku individuu. U skladu s elaboriranim shvaćanjem, gradi se koncept, koji nazivaju socijalnim kompetencijama, i opisuju ga na sljedeći način: „socijalno kompetentno je ono dijete koje je društveno osjetljivo jer ima razvijena socijalno poželjna ponašanja i socijalno kognitivne sposobnosti koje omogućuju da ta ponašanja primjenjuje usklađeno s potrebama drugih" (Jurčević Lozančić, 2016:21). Za postizanje ovih učinaka potrebno je ostvariti mnogo partikularnih ciljeva, od izgradnje stimulativnog i uključivog okružja, komunikacijske strukture razrješavanja konflikata, izgradnje partnerskih odnosa među brojnim akterima odgojnog procesa, reduciranja intenziteta utjecaja potrošačke kulture, do dekonstrukcije patrijarhalnih socijalnih koncepata i umanjenja ekonomskih razlika između pojedinih društvenih aktera. Važno je napomenuti da je odgojiteljska profesija, 
uz to što je iznimno propulzivna djelatnost, ujedno i djelatnost esencijalno okrenuta prema učinku, konkretno onom tipu djelovanja koje čini razliku u odnosu na postojeća stanja. Posebno važan aspekt suvremene odgojiteljske djelatnosti leži upravo u činjenici novog obrazovanja odgojitelja / ica koje se zasniva, osim na propulzivnom i uključivom djelovanju, konkretno, u osnaživanju kreativnih potencijala odgojitelja, poticanju i refleksivnog mišljenja, njegovom osposobljavanju za timski rad i procjenu odgojno-obrazovnog procesa (Jurčević Lozančić, 2015).

Upravo stoga vidimo ishodišnu točku iz koje kreću izazovi odgojiteljskoj profesiji. Djetetu pristupamo kao individui kojoj je potrebno omogućiti cjeloviti razvoj, uputiti je $\mathrm{u}$ one dijelove postojanja koji nisu isključivo izgrađeni kroz kulturne konstrukte, dok istodobno značajno oblikuju ljudsko postojanje. Ovime smo došli do središnje točke naše rasprave, nazovimo je brigom za životno okružje. Pozitivni utjecaj životinja na razvoj djeteta, kako smo ga htjeli ocrtati ovim radom, kvalitetan je podsjetnik da briga za životno okružje donosi užitak, radost, ljepotu a time i višedimenzionalne socijalne prednosti. Pri tome djetetova mašta i igra omogućuje mu doživljaj svijeta u kojem je sve moguće i u kojem se željeno uspješno ostvaruje.

\section{ZAKLJUČAK}

Ovim smo radom nastojali upozoriti na moguće dodirne točke unutar područja odgojiteljske profesije kao iznimno složene profesionalne djelatnosti te otvoriti put mogućim inspiracijama za etičko djelovanje koje bi oblikovalo budućnost sukladno parametrima razumijevanja, sućuti i brige. Za navedena shvaćanja veliki poticaj nalazimo u konceptu bioetičkog senzibiliteta kojim se nastoji izgraditi novi odnos prema životu općenito. Time smo sebe osudili na propitivanja veze između čovjeka i životinja, što nije samo biologistička nego i kulturna konstrukcija, u želji da dohvatimo pitanje možemo li mi kao pojedinci, kao civilizacija pa i kao ljudska vrsta, naučiti nešto od životinja, te kako bismo pozitivne odgovore na ova pitanja sagledali iz perspektive odgojiteljske profesije. Kažimo zaključno da u odgojiteljskoj djelatnosti vidimo mogućnost izgradnje i prijenosa novih oblika razumijevanja ljudskog postojanja i odnosa čovjeka prema cjelini života. Odgoj kao temeljni kulturni obrazac izgradnje humanog identiteta stoji pred izazovima vremena i smatramo da suvremeni odgoj mora humano razumjeti život te prema njemu izgraditi djelovanje utemeljeno na obziru.

Svjesni smo činjenice da smo u ovom trenutku tek na početku...

\section{LITERATURA}

Arambašić L. i Vizek Vidović V. (2000). Posredujuća uloga životinja u terapijskim programima. Hrvatska revija za rehabilitacijska istraživanja, 36(1): 17-24.

Brajša Žganec, A. (2003). Dijete i obitelj: emocionalni i socijalni razvoj. Jastrebarsko: Slap. 
Chernak McElroy, S. (2002). Životinje kao učitelji i iscjelitelji. Zagreb: VBZ.

Gopnik, A. (2011). Beba filozof. Što nam djeca govore o istini, ljubavi i smislu života. Zagreb: Algoritam.

Itković, Z. i Boras, S. (2003). Terapijsko jahanje i rehabilitacijske znanosti. Hrvatska revizija za rehabilitacijska istraživanja, 39(1): 73-82.

Jurčević Lozančić, A. (2015). The Road to Quality in the Theory and Practice of Early Learning: Identity of the Preschool Teacher Profession. Hrvatski ćasopis za odgoj $i$ obrazovanje, 17(1): 125-135.

Jurčević Lozančić, A. (2016). Socijalne kompetencije u ranome djetinjstvu. Zagreb: Učiteljski fakultet Sveučilišta u Zagrebu.

Kobešćak S., Selaković T. i Katalenić L. (2013). Poticanje dječjeg razvoja uz terapijskog psa: prikaz slučaja. Hrvatska revija za rehabilitacijska istraživanja, 49(2): 209-216.

Krznar, T. (2016). U blizini straha. Iznova o zaštiti okoliša u bioetičkom kontekstu. Karlovac: Veleučilište u Karlovcu.

Morell, V. (2013). Unutarnji svijet životinja. Misli i emocije bića s kojima dijelimo ovaj planet. Zagreb: Planetopija.

Morris, D. (1997). I čovjek je životinja. Zagreb: Prosvjeta.

Smojver-Ažić S. i Topalović, Z. (2010). Uloga kućnih ljubimaca u socioemocionalnom razvoju djece školskog uzrasta. Napredak, 151(2): 171-194.

Starc, B., Čudina-Obradović, M., Pleša, A., Profaca, B. i Letica, M. (2004). Osobine i psihološki uvjeti razvoja djeteta predškolske dobi. Zagreb: Golden Marketing - Tehnička knjiga.

Visković, N. (1996). Životinja i čovjek. Split: Književni krug.

Zuckerman Itković, Z., Petranović, D. i Barešić, K. (2007). Ergoterapija uz pomoć životinja. Medicina, 43: 155-164. 


\title{
POSITIVE INFLUENCE OF ANIMALS ON CHILD DEVELOPMENT AS A CHALLENGE TO EDUCATORS
}

\begin{abstract}
Tea Kevac and Tomislav Krznar
Abstract

In this paper our aim is to present some key aspects of the positive influence of animals on child development. We analyse various aspects of children's emotional and cognitive development, as well as the existing knowledge on positive influence of animals on child development, in an attempt to find a more solid theoretical foundation that could be used by today's educators. Moreover, humans today are experiencing negative effects on the global scale as a result of the destruction of natural environment and technicization of life. In this paper, therefore, we also try to think about the ways in which the intensity of this negative impact could be mitigated. We see one possible solution in the development of the so-called bioethical sensibility. By looking into the development of bioethics, we conclude that we need a new form of knowledge, as well as a new type of communication or mediation of that knowledge, which would be directed more towards the preservation of life. We see a potential for change in that direction within the modern education profession.
\end{abstract}

Key words: profession of education, childhood, child development, animals, sensibility, bioethics

\section{POSITIVER EINFLUSS DER TIERE AUF DIE KINDERENTWICKLUNG - EINE HERAUSFORDERUNG IN DER ERZIEHERTÄTIGKEIT}

\section{Zusammenfassung}

Tea Kevac und Tomislav Krznar

In dieser Arbeit versuchen wir einige grundlegende Aspekte des positiven Einflusses der Tiere auf die Kinderentwicklung zu zeigen. Wir analysieren Aspekte der emotiven und kognitiven Kinderentwicklung sowie konkrete Einsichten in einen positiven Einfluss der Tiere auf die Kinderentwicklung und versuchen zur Position zu gelangen, die wir als Grundlage der zeitgenössischen Erziehertätigkeit verstehen. Auf der anderen Seite wird unsere Gegenwart durch viele schwerwiegende Probleme gekennzeichnet, beispielsweise durch die Umweltzerstörung oder die Technifizierung des Lebens insgesamt. In dieser Arbeit stellen wir unter anderem die Frage, ob wir die negative Intensität erwähnter Geschehnisse vermindern können. Wir finden, dass eine mögliche Lösung im Aufbau einer bioethischen Sensibilität liegen kann. Die Grundeinsichten in die Entstehung und Entwicklung der Bioethik weisen darauf hin, dass neue Kenntnisse und neue Kommunikationsformen bzw. Vermittlung dieser Kenntnisse nötig sind, die zur Aufbewahrung des Lebens gerichtet wären. Im zeitgenössischen Erzieherberuf sehen wir Potential zu einer Änderung in dem Sinne.

Schlüsselwörter: Erzieherberuf, Kindheit, Kinderentwicklung, Tiere, Sensibilität, Bioethik 